\title{
Research on Performance Appraisal System of Primary School Teachers Based on AHP
}

\author{
Ning Cui \\ School of Humanities \\ Tianjin Agricultural University \\ Tianjin, China
}

\author{
Wei Zhang \\ School of Humanities \\ Tianjin Agricultural University \\ Tianjin, China
}

\begin{abstract}
Teacher performance appraisal is the important foundation for assessing and promoting teachers' achievement and improving teaching quality. Taking A primary school as investigation case, this paper tries to construct the teacher performance appraisal system and to explain the contents of indexes and its assessment standards. All classes of indexes are empowered with Analytic Hierarchy Process to guarantee the scientificity and effectiveness of the constructed system, providing referential basis for performance appraisal of primary school teachers.
\end{abstract}

Keywords-primary school teachers; performance appraisal; index system; analytic hierarchy process

Primary education is an important link of compulsory education in China. Since the development of performance pay reform in public institution, common schools started to implement performance pay [1]. Therefore, the discussion on teacher performance appraisal started to get into the public view. After several years' practice and development, some results of the performance appraisal of primary school teachers has achieved, but it is still in its early stage in general and has many problems. Thereinto, the constructing problem of performance appraisal system of primary school teachers is particularly prominent, which caused the effect of performance appraisal cannot be fully exerted, impeding the career development of primary school teachers [2].

\section{DEFINITION FOR PERFORMANCE APPRAISAL SYSTEM OF PRIMARY SCHOOL TEACHERS}

The performance of primary school teachers refers to corresponding performance evaluation activity received by teachers who work in common schools. This activity collects, analyzes and appraises the situations of teachers' work behaviors and results according to job objectives or performance standards with scientific methods of assessment [3].

\section{CASE ANALYSIS}

A primary school is a general common school under the government of the ministry of education in a district of Tianjin. This primary school implements the management system of president responsibility under the government of the ministry of education. This school sets a president who holds a concurrent post of legal representative and 2 vice-presidents to respectively charge the things of teaching, logistics, administration. In addition, this school sets several departments to charge the implementation of specific issues. There are 6 grades, 36 classes, more than 1200 students and more than 150 teaching and administrative staffs in this school.

\section{A. Problems Existing in Performance Appraisal of Teachers in A Primary School}

It has been a long time for the application of performance appraisal in A primary school's management. Although it has achieved the goals of improving teachers' performance and optimizing manpower resources management, the gap with the expected results of school is still large and it has the primal problems as follows:

\section{1) Incomplete appraisal coverage}

The visual angle of performance appraisal in A primary school was not wide enough, which was mainly focused on teaching achievements and leader's opinions with the narrow coverage. In addition, teaching achievements and leader's opinions were difficult to be balanced. Either the class examination results were predominant, which was deviating from the goals of new curriculum reform and quality education. Or leaders' opinions were referred to unilaterally. Therefore, the evaluation results were greatly affected by personal affection or conflict between leaders and teachers, or merely by non-objective factors and even the leaders' personal preference or prejudice, which led to unfair evaluation result and lack of reference.

2) Unclear contents of appraisal

When A primary school standardized the indexes of performance appraisal, it just paid attention to the assessment of virtue, ability, diligence, achievement or some general concepts with prominent $r$ and lack of and seriousness. Some indexes even had no correlation on examination contents, project setting and weight setting, which caused the operability of evaluation result was poor and difficult to obtain teachers' convince.

\section{3) Formalism of appraisal process}

The Formalism of performance appraisal has become one of the primal problems in A primary school. Leaders in primary school merely took performance appraisal as a tool of teaching guide and education for teachers and the evaluation result lacked applicability. As a result, every teacher merely 
took performance appraisal as going through a motion which must be gone in form which were indifferent to evaluation result and didn't truly analyze its process and result. On the teachers' development of teaching philosophy, teaching method and sense of responsibility, the effect of performance appraisal was limited, which deviated from the core goals of performance appraisal.

\section{B. Construction of Performance Appraisal system in A Primary School}

\section{1) Construction principles}

The scientific, rational and fair performance appraisal system of primary school teachers must be constructed according to the following primal principles:

\section{a) Combination of comprehensiveness and accuracy}

On setting teacher assessment standards, the work performance of teachers should be measured in all round with different angles as much as possible. During the practical appraise of school, the teaching achievements are not only be evaluated, but also the teachers' work degree, teaching attitude, teacher-student relationship, research assessment and major contribution should be investigated [4].

\section{b) Combination of practicability and fairness}

Teacher performance appraisal indexes should truly reflect daily education and teaching work of teachers, stick to practicality principle, change ideas, correctly grasp the relationships among each aspect of performance appraisal and promote teachers' continuous development intrinsically [4]. When pursuing the practicability of appraisal system, its fairness should be considered. To grasp the fairness in and out of school, industry standards should be referred and the fairness among staffs of each subject in school should be considered.

\section{c) Combination of guidance and feedback}

The performance appraisal system should have guidance for teachers. For the timeliness of appraisal, school should feedback the evaluation results to the teachers immediately. And school should give the corresponding encouragement to the teacher with the excellent marks and give the teacher with low marks corresponding reprimand and guidance to supervise and urge the improvements in working [5]. Only in this way can teachers' enthusiasm be aroused and their initiative and creativity be improved.

\section{d) Combination of qualitative and quantitative}

The principles of the combination of qualitative index and quantitative index should be held in the establishment of the performance appraisal system to avoid the absolute empiricism or an arbitrary assessment method based entirely on data for the science and rational, justice and equity of performance appraisal.

\section{2) Index setting}

The performance appraisal generally includes competency, behavioral attitude and work result. Form the job characteristics and career development of the primary school teachers, evaluation indexes of teachers are divided into four first-class indexes of quality and ability, research processes, teaching achievements and career development (objective level). And 7 second-class indexes and 24 third-class indexes are set based on that. The specific contents are as follows:

\section{a) Index of quality and ability}

The index of quality and ability mainly appraises the essential quality and ability of primary school teachers. The quality appraisal includes 2 third-class indexes: first, professional knowledge and skills. It requires that teachers have to be proficient in the content system of the courses and be able to accurately grasp the promising directions of the subject development and the latest results of this subject; second, general knowledge and skills. It refers to, besides the professional knowledge and skills, all kinds of knowledge required by teachers to carry out the teaching activities.

Ability appraisal includes 6 third-class indexes: first, language competence. In view of the characteristics of primary school teaching, teachers are required to use concise language, be lively and vivid with enlightening and guidance; second, writing skills. It requires the handwriting of teachers have to be neat and orderly and the written expression have to be correct; third, interpersonal skills. It requires that teachers can well communicate with students and their parents and have the ability to effectively coordinate the all kinds of $\mathrm{f}$ personal relationships in work; fourth, teaching innovative ability. Teachers should explore and improve the teaching methods, innovating the teaching means in their work for inspiring and cultivating students' innovative spirit; fifth, Logical thinking ability. It is used to appraise the grasp of logical relation and the clarity of thinking during the teaching and teaching and research process; psychological endurance ability. It is used to appraise the pressure bearing capacity and self-regulation ability of teachers.

\section{b) Index of teaching process}

This index mainly aims at the appraisal of the teaching process of primary school teachers and scientific research process, which adopts the assessment principle of teaching process as the main part and teaching and scientific research process as the auxiliary part.

Teaching process includes 4 third-class indexes: first, teaching attitude. It is used to appraise the sense of responsibility and work attitude of teachers toward teaching, which are the preconditions for teachers to do their own jobs well; second, this index is used to appraise form the fidelity, integrity, richness and cutting-edge of the teaching of teachers. Third, teaching methods. It is used to appraise that whether teachers can match the appropriate teaching methods in accordance with the teaching content and whether teachers can use various teaching methods together to arouse the students' interests. Fourth, teaching means. It is used to appraise whether teacher can expertly master and use the state-of-the-art facilities to improve the teaching efficiency and enrich the teaching contents.

Different from the university education, there are relatively few requirements for teachers in scientific research in primary school. But for deepening exploration of teaching research and teaching reform, and the mastery of teaching cutting-edge and 
hot content of teachers, scientific research is still an essential appraisal content. Teaching and scientific research process includes 2 third-class indexes: first, participation in teaching and scientific research process. This index is used to appraise the initiative of teachers' participation in teaching and scientific research activities and observation and commentary; second, progress of teaching and scientific research activities. For the effective supervision of the development of teachers on the approved topics and scientific research work (such as attending a lecture, setting up open class, demonstration lesson and match class), the school regularly inspects the progress of the topic research by asking teacher to fill in the "Research Progress Checklist" to properly control the project progress, ensuring both quality and quantity of the topics and teaching and research activities can be completed on time.

\section{c) Index of teaching and research achievements}

Based on the previous indexes of teaching process and teaching and scientific research process, this index continues to be used to appraise the teacher performance through teaching achievements and teaching and scientific research achievements. Teaching achievements include three third-class indexes; first, attendance. This index is mainly used to appraise the participation of teachers in teaching work and teaching and research activities organized by school; second, workload. School need to count all teacher's teaching hours in appraisal period and set standards of teacher's basic teaching time and scoring standards of different teaching types in accordance with the requirements of relevant departments of the Board of Education. In addition, it also includes the correction of homework and temporary assignment of relevant workload; third, teaching effect. This index is the appraisal of comprehensive ability in many ways of teacher for the adjustment of topic atmosphere, teaching content and time and enlightenment on students, which is an important reference index to evaluate teacher's teaching level.

Teaching and scientific research achievements include two third-class indexes; first, teaching and scientific research project. This index contains teaching research and scientific research. Teaching and research achievements mainly refer to open class or high-quality class with significant influence. Scientific research achievements include the paper published publicly and the scientific research project applying for approval. Second, teaching and scientific research awards. This index also contains awards statistics of teaching research and scientific research. Teaching research award project includes all level awards of teaching and scientific research which teacher obtained in appraisal period and the relevant awards are obtained by students which get excellent grades to take part in discipline competition above school level, science award and other activities. Scientific research award includes monograph, papers at all levels which published publicly and topic award.

d) Career development index

This index is used to appraise the endurance power of teacher career, including three third-class indexes; first, academic exchange. It refers to that teacher takes part in the academic exchanges of school level and above in appraisal period; second, professional training. It refers to that teacher participates in professional training of relevant subjects of school level and above and distance continuing education and learning. And the examination is qualified: third, degree graduate. It refers to that teacher improves learning with higher degree relevant to teaching subjects during their working life.

\section{Index Weight Assignment}

For the objectivity of evaluation index and the rationality of the result of teacher performance appraisal, this paper adopts Analytic Hierarchy Process (AHP) to assign the weight of index system [6]. And in order to ensure the rationality of index weight, a group, which is composed of 10 people of three leaders in charge of school teaching work, three school professional backbone teachers and four experts engaging in human resource management, is specially invited to complete the weight assignment work together. The final result is shown in TABLE I. 
TABLE I. INDEX SYSTEM AND WEIGHT ASSIGNMENT OF TEACHER PERFORMANCE APPRAISAL OF A PRIMARY SCHOOL

\begin{tabular}{|c|c|c|}
\hline First-class index & Second-class index & Third-class index \\
\hline \multirow{8}{*}{$\begin{array}{l}\text { Competency } \\
(0.2129)\end{array}$} & \multirow{2}{*}{$\begin{array}{l}\text { Knowledge accomplishment } \\
(0.0847)\end{array}$} & Specialty knowledge skill (0.0547) \\
\hline & & General knowledge skill (0.0327) \\
\hline & \multirow{6}{*}{$\begin{array}{l}\text { Ability accomplishment } \\
(0.1255)\end{array}$} & Language competence (0.0307) \\
\hline & & Writing skills (0.0209) \\
\hline & & Impersonal skills (0.0176) \\
\hline & & Teaching innovative capability $(0.0246)$ \\
\hline & & Logical thinking ability (0.0155) \\
\hline & & Psychological endurance ability (0.0162) \\
\hline \multirow{6}{*}{$\begin{array}{l}\text { Teaching and } \\
\text { research process } \\
(0.3041)\end{array}$} & \multirow{4}{*}{$\begin{array}{l}\text { Classroom teaching } \\
\quad(0.2451)\end{array}$} & Teaching attitude (0.0560) \\
\hline & & Teaching content (0.0578) \\
\hline & & Teaching method (0.0675) \\
\hline & & Teaching means $(0.0638)$ \\
\hline & \multirow{2}{*}{$\begin{array}{l}\text { Teaching and scientific } \\
\text { research process } \\
(0.0590)\end{array}$} & Teaching and scientific research activities $(0.0218)$ \\
\hline & & Teaching and scientific research progress $(0.0372)$ \\
\hline \multirow{5}{*}{$\begin{array}{l}\text { Teaching and } \\
\text { research result } \\
(0.3314)\end{array}$} & \multirow{3}{*}{$\begin{array}{c}\text { Teaching result } \\
(0.1713)\end{array}$} & Attendance $(0.0483)$ \\
\hline & & Workload $(0.0604)$ \\
\hline & & Teaching effect (0.0626) \\
\hline & \multirow{2}{*}{$\begin{array}{c}\text { Teaching and scientific } \\
\text { research result } \\
(0.1601) \\
\end{array}$} & Teaching and scientific research project (0.0726) \\
\hline & & Teaching and scientific research awards (0.0875) \\
\hline \multirow{3}{*}{$\begin{array}{c}\text { Career development } \\
\quad(0.1517)\end{array}$} & \multirow{3}{*}{$\begin{array}{l}\text { Career development } \\
(0.1517)\end{array}$} & Academic exchange $(0.0304)$ \\
\hline & & Professional training $(0.0535)$ \\
\hline & & Degree graduate (0.0638) \\
\hline
\end{tabular}

\section{CONCLUSIONS}

Through AHP, this paper discusses the performance appraisal system of teacher of A primary school and a set of index system applied to its performance appraisal is summarized based on performance appraisal status of this school. This system can provide necessary guidance and reference for the policy decision of setting teacher's appraisal reward and punishment, position recruitment, job promotion and training.

\section{REFERENCES}

[1] Yuan Suojun, Wang Mingbin. Implementation Status and Question on Performance Pay of Primary School Teacher in Jiangsu Province.
Journal of Jiangsu Education College (Social Science), 2013, (1): 18-23. (In Chinese).

[2] Guo Fang. Survey Research on Performance Appraisal of the Third Central Primary School in Xindian Town. Henan University of Science and Technology. 2011. (In Chinese).

[3] Meng Weiqing, Yuan Qing. Institutional Design Features on Teacher Performance Evaluation in Middle and Primary School_— Based on Multi-case Text Analysis of Teacher Performance Appraisal in Middle and Primary School. Educational Measurement and Evaluation (theory), 2014, (8): 26-30. (In Chinese).

[4] Eva Delvaux, Jan Vanhoof, Melissa Tuytens. How May Teacher Evaluation have an Impact on Professional Development? A Multilevel Analysis[J]. Teaching and Teacher Education, 2013(36):1-11.

[5] Melissa Tuytens, Geert Devos. Stimulating Professional Learning through Teacher Evaluation: An impossible Task for the School Leader [J]. Teaching and Teacher Education, 2011(5):891-899.

[6] Xu Qian. Index System Design on Teacher Performance Appraisal of University Teacher Based on AHP. Journal of Qingdao University of Science and Technology (social science), 2008, (4): 89-90. (In Chinese). 